\title{
Atualizações em Esclerose Lateral Amiotrófica
}

\section{Mamede de Carvalho}

Neuromuscular Unit, Institute of Molecular Medicine - Faculty of Medicine Dept Neurosciences, Hospital de Santa Maria, Lisbon, Portugal

A esclerose lateral amiotrófica é uma doença degnerativa progressiva, de curso inexorável e sem tratamento que permita suster a sua evolução. $\mathrm{O}$ conhecimento dos processos moleculares de morte neuronal é essencial para esse fim.

Recentemente algumas descobertas têm sido muito importantes, permitindo o avanço da compreensão dos processos subjacentes à morte neuronal. Várias novas mutações têm sido associadas com a doença, como as das proteínas VAPB, Angiogenin e a TDP-43. Mais recentemente, a mutação no gene FUS, responsável por uma proteína com funções no "splicing" e transporte do RNA, tem implicações importantes na compreensão do papel do RNA no processo de morte celular, na medida em que o gene TARDP produz uma proteína com funções similares.

Outro ponto de importância reside no renascer da importância dos astrocitos para a sobrevivência dos neurónios motores. Este ponto tem origem no conhecimento da disfunção dos seus receptores (GLT1) na recaptação do glutamato nesta doença. Actualmente, sabe-se que células gliais saudáveis aumentam a sobrevida de neurónios afectados, por outro lado astrocitos com a mutação SOD1 são tóxicos para neurónios não afectados. Estes achados suportam que para além do implante de células progenitoras do tecido nervoso, os precursores gliais são uma potencial alternativa de tratamento nesta doença.

A disfunção do transporte glutamatergico dos astrocitos pode ser desencadeada pela hipoxia, este aspecto sugere uma relação entre moleculas como VEGF e a angiogenina e 
excitoxicidade glutamatergica. Por outro lado pode reforçar a importância da oxigenação dos tecidos.

Os avanços recentes são promissores e permitem antever um melhor tratamento. 